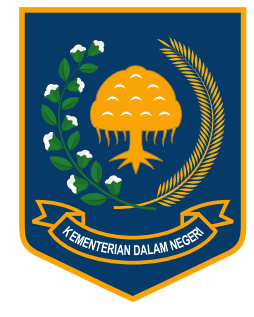

Jurnal Bina Praja 8 (1) (2016): 163-173

Jurnal Bina Praja

e-ISSN: 2503-3360 | p-ISSN: 2085-4323

Accreditation Number

735/AU2/P2MI-LIPI/04/2016

http://jurnal.kemendagri.go.id/index.php/jbp/index

\title{
The Role of Non-Governmental Organization (NGO) in Advocating the National Security Bill
}

\author{
Yusa Djuyandi ${ }^{1, *}$ \\ ${ }^{1}$ Department of Political Sciences, Universitas Padjadjaran \\ Jl. Raya Bandung - Sumedang, Jatinangor, Sumedang, Indonesia
}

Received: 1 February 2016; Accepted: 19 May 2016; Published online: 31 May 2016

\begin{abstract}
The role run by a coalition of NGOs in advocating the National Security Bill aimed at encouraging the birth of national security policy to appropriate to the purpose of reform. However, until now the role of NGOs in advocating National Security Bill has not been able to encourage the authorities to reconstruct the draft of national security policy that is consistent with the objectives of security sector reform. This study is conducted to analyze the role of NGOs in the security sector reform in Indonesia, particularly through the advocacy of the National Security Bill. The method used in this study is a qualitative method. The result shows that NGOs, which are members of the KMSRK, have been running the multiple roles, such as: popularly involved in policy making, providing political education to the community, promoting or encouraging reform, and promoting the interests of the community. The study also suggests the existence of new findings of the role of NGOs, which is forming a coherent unity of interests.
\end{abstract}

Keywords: NGO, national security, advocacy

\section{INTRODUCTION}

Policy or legislative product in security sector is an important part in strengthening the security sector reform process. Although there are already the Law about Police (Polri), the Indonesian Armed Forces (TNI), National Defence and Intelligence, but the government and the House of Representatives (DPR) so far have not found a deal to enact the Law draft (Bill) of National Security as the policy that overshadows defense and security sectors. On the other hand, the existence of the National Security Bill has been deemed necessary.

The necessity of National Security Bill cannot be separated from the flaws that still arise from a variety of legislation devices that were born after the separation of military and police. Institute for Defense Security and Peace Studies (IDSPS, 2008: 3) stated that: "Either Law No. 2 of 2002 about Police, Law No. 3 of 2002 about National Defense, or Law No. 34 Year 2004 about the Indonesian National Army still poses a problem in the form of lack of space for coordination and operational synergies in the field."

National security policy is needed so that the Indonesian people have a clear reference in defining security threats and defenses, organize the state apparatus to address each of the different threat, threat mitigation process, and the process of interinstitutions coordination. National Security Bill exists to answer that urgent matter, although the course of the issuance of the bill actually got a lot of stumbling due to the persistence of disagreement between the National Police (Polri) and the TNI, central and local governments, and between the government and DPR. (Tempo.co, 2012).

The debate between Polri and TNI regarding National Security Bill ever occurred when the Commissioner General of Police (ret.) Drs. Adang Daradjatun, as the former deputy chief and former Chairman of the Police Reform, revealed that there are still many problems that arise in the National Security Bill, and therefore the National Security Bill at least needs to be reviewed (Daradjatun in Al Araf and Aliabbas, 2007: 89).

Although the National Security Bill is considered important, and the draft has been revised several times within 8 (eight) years in discussions between the government and DPR, but DPR through a Special Committee (Pansus) of National Security Bill found the substance of National Security Bill proposed

\footnotetext{
* Corresponding Author

Phone : +62 8179242566

Email : yusa.djuyandi@unpad.ac.id
} 
by the government still has the potential to violate human rights (HAM). The potential human rights violations arise in the setting of threat, setting of intelligence activities, intercepts, and arrests. National Security Bill is also considered to have the potential in causing authority overlapping between TNI and Polri, as well as threatening the freedom of the press. In general, the National Security Bill committee of DPR considers there are still many gray areas in the National Security Bill that could potentially lead to the abuse of power (dpr.go.id, 2012).

National Security Bill proposed by the government, in addition to getting the attention and criticism of the legislature, has also received attention and criticism of the coalition of NonGovernmental Organizations (NGOs) on security sector reform. As the institutions of political infrastructure or non-state actors, NGOs have an important role in security sector reform, particularly in the drafting process of National Security, because the organization is not only to criticize but also to contribute in providing input to the government and DPR for substances that become the issues of the National Security Bill.

Some NGOs, which are members of the Civil Society Coalition for Security Sector Reform (KMSRK), ARE concerned that the National Security Bill may be misused by the owner of power to fight the groups that are critical of the power (ELSAM, 2012). The concern of a number of NGOs is similar to the views of the majority members of DPR, particularly those who are part of the Special Committee of the National Security Bill.

The NGOs that are members of KMSRK think that there are approximately 25 problematic chapters in the National Security Bill that threaten freedom and democracy. Some chapters include the following: In Article 14, paragraph 1, which declares that a state of martial law is enacted when there is social unrest; Article 17, paragraph 4, which states that the actual and potential threat is determined and regulated by Government Regulation; Article 22, paragraph 1, which still utilizes the implementation of National Security that involves the active role of state intelligence; Article 27 paragraph 1, which states that TNI Commander may establish operating policies and military strategies based on the policy and policy strategy of the organizers of the National Security; Article 54 (e) that regulates the special powers held by national security elements in the form of the rights to intercept, inspect, arrest and take forceful action (Araf, 2013).

NGOs' critical stance on the substance of the National Security Bill is undertaken not to hinder the process of the birth of national security policy, but rather on how the draft policy is able to birth well through rational, critical, and open consideration, so it can be accepted by society.

The existence of NGOs as the institutions of political infrastructure is needed to support security sector reform, especially in the advocacy of the National Security Bill. As the institutions of political infrastructure, NGOs in KMSRK provide critical and argumentative input, pressure, as well as a view to the political superstructure institution about the National Security Bill. Various entries submitted by them can be an important point for the political superstructure institution as the policymakers of the National Security Bill. As Theo L. Sambuaga (in Al Araf and Aliabbas, 2007: 21) expressed the need to involve all stakeholders, including NGOs, to examine and discuss in detail the preparation of Law on National Security.

Despite being involved in various processes of discussion on the draft law of security sector, including in the advocacy process of the National Security Bill, yet the role of NGOs in advocating the National Security Bill has not been able to push the holders of political power, such as the government and DPR, to reconstitute the draft of national security policy in accordance with the objective of security sector reform. The occurrence of these conditions has caused problems on the efforts to strengthen security sector reform. Of these problems, then the author formulates research questions about How the role of NGOs in the advocacy of the National Security Bill?

The role of NGOs in the advocacy of the National Security Bill becomes an interesting issue to study because its existence is considered able to promote and assist the birth of national security policy that orientated towards the purpose of reform movements and public interests.

The study on the role of NGOs is a study that has been done by many people, some studies on the role of NGOs have different focus between one another. Herewith are pointed out some of the focus of previous studies on the role of NGOs: First, is the study that focuses on the role of NGOs in combating corruption in various regions in Indonesia, the study looks at how NGOs play the role in uncovering and preventing corruption (Mufrikhah, 2011; and Mukhibbin 2006).

Second, is a study with a focus on the role of NGO in strengthening civil society, in which NGOs implement community empowerment, public advocacy, and oversight of local government policy (Grace, 2003; and Praja, 2009). Third, is a research with a focus on the role of Non-Governmental Organizations (NGOs) in the labor movement in Indonesia, which is viewed from a historical perspective where NGO became involved in social and political issues (Ford, 2003).

Aside from the studies mentioned above, there are other studies that talk about the role of NGOs in 
relation to the security sector, as a study conducted by Hadiwinata (2004) on the Role of NGOs in the Protection of Human Security in Indonesia. However, the protection of human security emphasizes more on the protection from the poverty aspect. There is also a study by Yunanto, et al. (2008). Although not discussing the role of NGOs, but the study also discusses the civil society organizations (CSOs) in the advocacy of Security Sector Reform in Indonesia in the period of 1998-2006. But the study on the CSO is more focused on the effectiveness of CSOs' strategy in security sector reform advocacy, particularly in encouraging, influencing, and supervising TNI, Polri and BIN, the Government, and Parliament.

A study on the role of NGOs is also conducted by Gorman (2002), which examines the role of NGOs in developing countries in addressing the challenges of demographic transition in the late 20th century. In addition, there is another study conducted by Theuri (2014), in which the study examines the role of NGOs in the process of formulating a policy on HIV in Kenya.

The studies in other countries about the role of NGOs in the security sector can also be found. As such conducted by Mufti (2015) and Cawthra (2013). Mufti (2015) in his study analyzes about the complexities and development of interaction between NGOs and the security services in Lebanon. He views the Lebanese NGOs' involvement and intervention in the field of security sector reform, such as the role of supervising the government, lobbying, and campaigning to build public awareness. While Cawthra (2013) in his study illustrates the role of NGOs in helping to formulate the security policies of countries in southern Africa such as Swaziland, Zimbabwe, and South Africa. The role of NGOs in the formulation of security policies is not to intervene the government, but to help the government formulate policies based on research orientation.

From both studies above, the study conducted by Cawthra (2013) has a closeness with the study carried out by the author. However, the role of NGOs as studied by Cawthra has a different study locus with this study. Additionally, the study by Cawthra also sees how the relationship between the role of donor countries and the role of NGOs which received grants to help the governments in some countries in southern Africa in formulating national security policy,

Based on the exposure of the previous studies, it can be concluded that up to now it can be said that there has been no research that examines the role of NGOs in advocacy of the National Security Bill by the Civil Society Coalition for Security Sector Reform.

The existence of NGOs as new social movements makes NGOs one of the organizations that are taken into account by the government for its existence, including making political policies related to public interest. The considered existence of NGOs in the political decision-making process is, according to Sanit (1985: 51), because the NGOs conduct political activities and have their own agenda.

Although the existence of NGOs is taken into account in policy making and is considered quite concerned, but according to Willetts (2012: 1), NGOs is one component of the social movement, and as the part of the social movement, NGOs must be independent of the governmental power.

As stated also by Iriye (2004: 30 ) that "NGO as a voluntary non-state, non-profit, non-religious, and non-military association." Iriye's view reinforces the view that NGOs, as a social movement of society, must be independent (non-state, non-profit, nonreligious, and non-military).

The importance of NGOs to be independent, away from the influence of power, is because one purpose of the NGOs is to develop civil society (hikam, 1999: 6; and Gaffar, 2006: 205). They also see the NGOs as the backbone of civil society. The term NGOs itself was born out of the paradigm of civil society which manifests in a variety of social and political places in public. The role of NGOs in the advocacy of the National Security Bill is very important to ensure that the government does not create a policy that can harm people. As for example, NGOs put pressure on the government so that the National Security Bill does not conflict with the values of democracy and human rights. For NGOs, putting pressure on the government is very likely, because NGOs is one component of social movement that is independent of government power.

In conducting the study analysis with the above title, the author utilizes the theory of the role of pressuring groups/NGOs by Peter Joyce. In which according to Joyce (2008: 111-112), in supporting the process of a democratic political system, NGOs have a role to be: popularly involved in policymaking; provide political education; promote or encourage reform; and put forwards the interests of minorities.

Although the theory by Joyce has a closeness with the phenomenon of the study, but this theory does not see another aspect of the role of NGOs in Indonesia in its efforts to strengthen security sector reform in Indonesia. This study sees that there is another role played by NGOs, which are members of the KMSRK, as they seek to strengthen the security sector reform through the advocacy of National Security Bill. That role is to create or form a coherent interest unity, through the unity of ideas, words or sentences, and actions. With the theory utilized, it is expected that this study can answer the purpose of research, which is to analyze the role of non-governmental organizations in the advocacy of the National Security Bill. 


\section{MeTHOD}

This study uses the qualitative method. The source of data is divided into two types of data sources, namely primary and secondary data sources. Primary data is the data obtained directly through field observation and interview with informants. Secondary data is obtained through documentation relevant to this study.

The observation is carried out on the activities of NGOs' role, which is part of KMSRK, in advocating the National Security Bill. While the documentation analysis is carried out on various documents related to the role of NGOs in advocating the National Security Bill. The NGOs are limited to the NGOs which are members of the Civil Society Coalition for Security Sector Reform (KMSRK).

The interview is conducted with informants, namely: Chairman, Vice Chairman, and a member of Commission I of DPR, Coordinator of KMSRK, leaders and/or representatives of NGOs in KMSRK (Lesperssi, IDSPS, and KontraS), and academics who are competent in the study of the role of NGOs.

The validity test of the data in this study is conducted through triangulation. To maintain the validity of the data or study, conducted the efforts based on the principles of triangulation. In this study, triangulation is conducted on data sources, as well as using a variety of supporting references to prove the fact that data has been found by the author.

\section{RESULT AND DISCUSSION}

In strengthening the security sector reform process in Indonesia, particularly through the advocacy of the draft Law on National Security, NGOs can carry out a number of roles, among which: Popularly engage in policy-making; Provide political education; Promote or encourage reform; and Put forward minority interests (Joyce, 2008: 111-112).

\section{A. Popularly Engage in Policy-Making}

The involvement of NGOs in advocating the National Security Bill basically also cannot be separated from the discussion on the importance of achieving good governance. The discussion on good governance cannot be separated from the issue of the transformation of government because the government was popular before governance. During the New Order era, state (government) was considered all-powerful (omnipotent). The new perspective that gave birth to governance and good governance will not allow seeing the government as a giant institution anymore that uses its authority by force over the entire territory and population, as well as controlling the influence on its policies and institutions. In his view, Djakfar (2011: 30) stated that the government is understood more as a giant institution that uses its authority by force over the entire territory and population. The government is everything and omnipotent, which is directly perceived by the public.

The pragmatic shift from government to governance essentially hinting about the need for government to involve various stakeholders outside the government in policy making processes related to public interest. Djakfar (2011: 26) states that "the Government in good governance has the functions to create conducive political and legal environment, while the public plays a positive role in social, economic, and political interactions, including participating in economic, social, and political activities."

From that perspective, it is understood that the spirit of good governance is to ensure that democratic rights are in the hands of the people, one of which is implemented from the openness of the government to involve the public in the policymaking of the National Security Bill.

In order for a policy to not harming the interests of the people, then the process of formulating a policy by the government needs to consider the side or the principle of accountability. Despite legislative function is under the authority of the legislature and the executive, which is carried out jointly, but it is not always be monopolized by those institutions. It should be noted that the legislature and the executive can not be separated from the elements of a political party or political interests of certain groups, despite the discourse that their existence within the government and parliament must be professional.

The existence of the element of party or group that has a certain interest in government can bring out problems on the birth of policies detrimental to the people if it is not accompanied by public oversight and participation in the policymaking. What is proposed by Naswar (2012: 5) must be noted, namely that the party is the 'kitchen' to the formulation of state policies that must be fought by the cadres in DPR and the executive. In the context of Indonesia, strict party discipline had shackled the members of DPR to be critical especially to keep their distance with their party policy line. The author sees that the context of the view as expressed by Naswar is not only applicable to the party cadres in the government, but it can also apply to members of TNI in the government because under Article 47 paragraph (5) of Law No. 34 of 2004 on the Indonesian National Army (TNI), the TNI Commander is entitled to provide guidance to those working outside TNI environment.

On the basis of the above condition, the popular or active involvement of NGOs in the formulation of the National Security Bill is important and necessary. On one hand, NGOs should actively supervise 
and advise the government on the discussion of the National Security Bill, on the other hand, the government must also actively involve civil society organizations to participate and provide input on the National Security Bill.

Related to the condition, some informants have said that the discussion of the National Security Bill is already open and involves a variety of components outside the government. Both the government and DPR also involve the active participation of civil society, especially NGOs, to provide criticism, suggestions, and feedback on the National Security Bill. The Executive Director of Lesperssi also said that the discussions of the National Security Bill have been conducted several times conducted by the Ministry of Defense, DPR, journalists, and experts (Siddiq, Makaarim, \& Putra, 2014).

In addition to providing feedback on the National Security Bill through the forums provided by the government and DPR, several NGOs in KMSRK, such as KontraS, also encourage street actions. The actions demand DPR to reject the National Security Bill proposed by the government, citing that several articles in National Security Bill have the potential to violate human rights and undermine the democratic system that is being built (Hernowo \& Araf, 2014). In other words, from the information, it can be said that the group of NGOs has also done activities or operations as a pressure group.

The Operation of pressure group, as done by some NGOs in KMSRK, is an operation performed in order to influence the government policy. This operation is also one form of encouragement for promoting the interests of upholding democracy through freedom of opinion and criticizing the government without fear. The process of democratization in Indonesia during this current reform era is clearly colored by the role of pressure groups, which demand the government to understand people's interests and not the opposite where the people serve the government.

As political infrastructure institutions, NGOs also need to encourage community participation in providing input and criticize the National Security Bill. From the result of the study, the NGOs which are members of KMSRK have been actively encouraging public participation in the discussion process of the National Security Bill, in which the process is done through a variety of discussion forums. Discussion activities between NGOs and the public in addition to accommodating the ideas or views of the people can also raise awareness of the problems they will face.

Just as stated by the Director of IDSPS that the result of his visit to several regions eventually gets the public to provide input on National Security Bill. And the people who were involved by IDSPS and KontraS to provide input are not limited to any group so that it is ranging from ordinary citizens, academics, and politicians to get involved (Makaarim \& Hernowo, 2014). The effort to encourage community participation is also done by Imparsial and Lesperssi, but the segmentation is limited, where they only invite and encourage academics, politicians, and activists of movements to participate in criticizing and providing input to the National Security Bill, which then the result of the discussion is submitted to the government (Putra \& Araf, 2014).

\section{B. Providing Political Education}

As political infrastructure institutions, the role of NGOs can also be seen from what they did in order to provide political education to the community. By providing political education to the community, the NGOs also help to encourage public awareness to be concerned on the issue of the National Security Bill formulation. In analyzing the political education provided by NGOs to society, the author considers several aspects, namely: NGOs' explanation to the public about the stance they believe in, NGOs encourage the view that they hold to the public, NGOs conduct some kind of investigative journalism that will result in the increased of surveillance and public awareness on the government activities.

Explaining to the public about the attitude they believe in means explaining to the public as to why the NGOs, which are members of KMSRK, reject the draft of the National Security Bill. The step to explain to the public is an important first step to being done before the NGOs encourage their views to the public. If the NGOs do not explain in advance the reasons why they reject the National Security Bill, it will be difficult for them to push the vision they believe in the public.

From the observations that have been made, it is known that the NGOs which are members of KMSRK have also conducted a series of activities that explain to the public related to the attitude of those who reject the National Security Bill. The argument given to the public is that the National Security Bill can be a threat to the rule of democracy, freedom and human rights protection. As for the means used by the NGOs coalition members to perform these activities are different from each other; there are some which only use a press release, but there are also some which use press release and discussion.

Besides having to explain their attitude to public, NGOs in the coalition have also pushed theirs vision to the public. It is known from an informant statement, who is the KMSRK coordinator. According to him, there are a lot of support from the community, starting from students, workers, and academics who reject the National Security Bill. Even some of the community groups also took part in the street actions. Based on the exploration 
conducted, the rejection actions of some elements of society against the National Security Bill emphasize a lot on the issue of the importance of maintaining freedom of association, assembly, and expression (detik.com, 2012). The emergence of this awareness shows that the effort of NGOs is essential in building political awareness of the people.

The community will certainly need to have a preference on why they need to support NGOs to participate in rejecting the National Security Bill, and this can only be done if the process is accompanied by the encouragement of thinking about the importance of democracy, freedom, and human rights protection. Without the encouragement of thinking or view to the community, the NGOs will find it difficult to get support from the community to urge governments to revise some articles in the National Security Bill.

The Effort to encourage the view of democratic values can be conducted because democracy can build public awareness, that democracy provides an opportunity for aspiration and voice of the people. In a democracy, needed the participation of the people emerging from political awareness to get involved and take part in the government system. In various aspects of life in this country, actually, the people have rights to participate in determining the policy measures of the country, and therefore the public need to have that consciousness.

Although many NGO which are members of KMSRK have explained and promoted their views to the public, but in terms of the implementation of investigative journalism, not all members of KMSRK do it. Lesperssi is one of four NGOs being studied, which is not involved in an activity such as investigative journalism. As revealed by the Executive Director for Lesperssi that the National Security Bill does not really require the process of investigative journalism, and therefore they do not do it. As for IDSPS, KontraS, or Imparsial, they consider the activity of investigative journalism is essential and hence they conduct this activity.

The process of investigative journalism is important, this process is a reporting method for listening to the truth of the case or incident. Investigative journalism is related to evidence that can be shown or can not be shown (off the record) and the data from anonymous sources or from the wrecker of a case. Those who conduct the investigation are required to be able to see the gap of violations, explore it with great reportage energy, make hypotheses, analyze, and eventually write the report. As, for example, conducted by KontraS, where, according to the informant of KontraS when visiting some areas to collect some evidence on the repressive measures of the forces in addressing the attitude or the demands of the public, particularly to the demonstrations. The evidence is collected, one of them through a process of discussion with several people. From such evidence, KontraS perceive and show that the forces themselves are unable to perceive well the form of a threat because they still apply the old ways to crack down civil society actions.

\section{Promote or Encourage Reform}

In order to promote or encourage the reform in security sector, NGOs need to arise things or issues that intersect with the aim of reforming the security sector itself, NGOs can also promote their rejection of policy proposal (National Security Bill) which they consider contrary to the interests of society because potentially violating human rights and lead to abuse of power.

That the dynamics of the security sector reform that have undergone for more than ten years, still leave many shortcomings in the achievement of security sector reform agenda. Among them that is still unclear is the legislative framework of national security as stipulated in the National Security Bill, the draft policy still contains several articles that are considered problematic because it is contrary to various terms and the important issues that become objectives of the security sector reform itself, which is related to the issue on the enactment of democracy, political freedom and freedom of expression, human rights protection, and TNI professionalism. Laksmana (2010:4) revealed that in managing the defense transformation of democracy has needed an overhaul of the system that includes an emphasis on democracy, human rights, professionalism, and so forth.

Of the various issues that are important to be raised, then the author tried to observe any issues raised by NGOs in KMSRK in encouraging the strengthening of the security sector reform through the advocacy of the National Security Bill. The result of interviews with several informants, including the coordinator of KMSRK, shows that a number of NGOs who are members of KMSRK the least have raised various issues in addressing the National Security Bill. Some of the issues referred are in accordance with what the author has pointed out above, namely the issues of military professionalism and upholding human rights. The issues are considered important to be raised as they are in direct contact with democratic processes and human rights protection.

The issue of interception is also an issue which, by the Executive Director of Lesperssi, is considered important to put forward to the public, in addition to other matters similar to what has been disclosed above, such as the issue of coordination or relationship between TNI and Polri, the categorization of threat, the determination of civil and military emergency, as well as who are the responsible parties, and about the intelligence 
agencies that could take projustisia action. Related to the vagueness categories of threats and security management, especially about who are the responsible parties, becomes important to raise so that later the issue does not result in the issue of threats abuse.

The issue of human rights violations, one of which may arise from: the repressive attitude of apparatus, unclear categorization of threats, including which authority is responsible, as well as the opportunity to degrade again the professionalism of the military by giving them opportunities to engage in civil domains, are some of the many issues that also pinted out by IDSPS and KontraS to public. The rise of these issues to the public is an effort that can be done by NGOs in raising public awareness.

In addition to the various issues raised to the surface, NGOs in carrying out their role also need to reject the policy proposal deemed contrary to the public interest. Related to the attitude of NGOs in KMSRK on the National Security Bill, from the information of informants, it is known that they generally have rejected the National Security Bill formulated by the government. The reason for rejection is different for each NGO, such as Imparsial that consider the National Security Bill is unnecessary at all because the country already has the Law on Defense, Law on TNI and Law on Polri. However, even in a position to refuse, Imparsial still prepares the measures to oversee the formulation of the National Security Bill if the government still wants to legalize it (Araf, 2014).

While several other NGOs such as Lesperssi, IDSPS, and KontraS from the beginning are in the position to consider the National Security Bill necessary in order to support security sector reform process, but they still want some changes to the substance of the National Security Bill. However, according to the Executive Director of IDSPS, so far the changes made by the government on the National Security Bill is not substantial, "The government has always said it is revised, but the change is, according to our opinion and including DPR, not substantive."

\section{Put Forward Minority Interests}

Speaking about the minority in the political sphere is not always synonymous with a small amount in a society, the minority does not need to be numerical because it may include under normal groups with regards to the dominant group, one of them is in terms of political power. Liliweri (2005: 101) revealed that minority can also mean those who certainly do not have any power.

Related to this fourth indicator, namely to put forward the interests of minority (the people), then there are some things being analyzed by the author, in which as the pressure group, NGOs need to: Have the ability to advocate the opinion or matters of concern of minorities, provide a vehicle in which minorities can articulate their needs, Encourage policy makers to pay attention to minorities.

From the information conveyed by all informants, the author obtained information that NGOs which are members of the KMSRK have been advocating various opinions or matters of community concerns to the government and DPR. As, for instance, proposed by the Coordinator of KMSRK "If advocating, we've done it, for example, we convey the demands and expectations of the people to the government and DPR." Likewise with the informants from IDSPS and KontraS which revealed that they already convey public findings and views to all stakeholders, namely the government and DPR.

The ability of NGOs to advocate their ideas, opinions and public attention on the issue of the National Security Bill is significant, given that the problem is in the substance of the draft policy, which concerns about potential human rights violations, restrictions on the freedom of opinion, the abuse of power by the government, and the degradation of professionalism of TNI.

From interviews with a number of informants, the author received information that a number of NGOs who are members of KMSRK, such IDSPS, Lesperssi, KontraS and Imparsial, also prepare a place and space for people to discuss and express their views on the National Security Bill. At the time NGOs become a vehicle for people to be able to articulate their needs and concerns, the NGOs have contributed to change. Although NGOs are not the instrument for change itself, but NGOs have helped to articulate the power of the people, as well as solidarity with the people.

Related to the question of whether all the NGOs who are members of KMSRK have prompted policy makers to consider the interests of the public and its demands in reformulating the National Security Bill, the entire informants from NGOs feel that they already and always encourage the government and DPR to consider the inputs or the demands the public. Even, according to the Director of IDSPS, the government should not close themselves to the demands of communities that have been conveyed.

According to the view of the author, the attention given to the demands of society by the holder of power actors can be used as a parameter to ensure that the democratic process is already running. So is the case with the issue of the National Security Bill, NGOs need to continue to encourage the government to consider the interests of society.

\section{E. Forming Coherent Unity of Interest}

Aside from the role proposed by Joyce, there are other roles that appear in the dynamics of the NGO movement in Indonesia. That role is to form 
a coherent unity of interests. Forming a coherent unity of interest can be regarded as a role because it is in line with the view of Kantraprawira (1987: 32 ), where he says that the role is an orientation or a conception of the part played by a party in its social position.

In Indonesia, the struggle of NGOs to strengthen the security sector reform, particularly in advocating the National Security Bill, is not conducted as per institutional. The trend found is that the NGO movement is conducted as collective institutional. The establishment of the Civil Society Coalition for Security Sector Reform (KMSRK) is a concrete manifestation of the collective struggle. When some NGOs form a coalition and fight together on the grounds of having a coherent or common interests, it has already indicated their roles. The reason is a coalition of NGOs have demonstrated their orientation that is purposefully played in their social position.

Although NGOs in KMSRK have different activity or movement backgrounds, but when talking about the interests of coherent unity then the unity of ideas, the unity of words or sentences, and unity of action among members of the coalition are needed. The need for unity is because the coherent itself has the same meaning, harmonious or compact. With coherence, conceptually NGOs in KMSRK can easily achieve their objectives, even more, powerful or solid in facing the government.

Related to the unity of idea, referring to the view expressed by Makaarim (2008), it is known that the background in coalition building among civil society is due to the emergence of the same idea to conduct strategic advocacy on draft legislation in security sector reform. Some civil society groups feel the need to oversee the formulation of policies and revoke policies that are contrary to democracy, the values of human rights protection, and good governance. Their ideas and work intersection between actors in civil society lead to a gradual change in the relation of security sector reform advocacy, so in the end, the relation between civil society actors become more constructive.

In line with its development, the relation between civil society actors is then coordinated in the form of a medium called coalition. In addressing the National Security Bill, NGOs in KMSRK also have the same idea about the need for democratic legislation draft, uphold the values of human rights and strengthen the rule of civilian political authority. This unity of idea then makes the members of the coalition feel the need to address and criticize the substance of the National Security Bill. Based on their review of the National Security Bill, they assess the substance of the National Security Bill is still far from such expectations.

Due to the substance of the National Security
Bill is still considered problematic and contrary to their three ideas, then NGOs in KMSRK have a unity of idea to reject the National Security Bill. In their statement to the media, the NGO coalition members have the same thought or idea that the National Security Bill, because of threatening the civil liberties and democracy, existence should be rejected (Sasmita, 2012).

Although the NGOs in KMSRK have the same idea to reject the National Security Bill. However, from the testimony of informants, there are different ideas about the future of the National Security Bill. The first idea is that the National Security Bill can still proceed with a number of improvements, even the National Security Bill is considered still needed to support the security sector reform process. The second idea is that the National Security Bill is absolutely unnecessary. Imparsial and AJI are two NGOs that believe the legislative reform in the security sector is enough with the Law on TNI, Law on Polri, the Law on Defense, and Law on Intelligence (Firmansyah, 2015).

From the description of the unity of the ideas above, it can be argued that the unity of ideas between NGOs joined in the coalition occurred only at the start of the coalition formation. However, in addressing the National Security Bill, began to emerge different ideas among members of the coalition, in which whether the National Security Bill is necessary or not in completing the legislative process of the security sector reform. The difference in ideas also shows the differences of interest among members of the coalition that can lead to the coalition force becomes weakened in urging the government.

The unity of words or sentences for a coalition is as important as the need for unity of ideas. Simply put, a powerful and effective coalition can be associated with the word unity among its members. Although a coalition that is formed is not always permanent, but since the coalition is formed because of their common interest to fight for a case or a destination, then before that goal is achieved, unity is needed among coalition members, including the unity of words.

In the efforts made by the NGOs in KMSRK to strengthen security sector reform, reflected the differences in attitudes and words among members of the coalition in response to the existence of the National Security Bill. The difference in words between the coalition members can already be seen when there is a difference between their ideas about whether or not the National Security Bill is necessary to complete the process of security sector reform, particularly in the field of legislation. Imparsial and other Coalition members such as AJI made a statement that the National Security Bill is not required, in contrast with other NGOs such the 
statement of Lesperssi, IDSPS, and KontraS which precisely consider that the National Security Bill is still necessary even though with a number of improvement records.

The lack of the unity of words among NGOs of the coalition becomes a problem because this condition reflects how unsolid the members of the coalition are because of differences in interests that may be too large. For the security sector reform process itself, the absence of the unity of words between NGOs of the coalition could weaken the struggle for civil society groups in pressing the government to bring forth new legislation that is democratic and not restraining civil liberties. On the other hand, it is also easier for the government to carry out a variety of approaches to some members of the coalition to discuss the National Security Bill.

The lack of the unity of words among the NGOs of the coalition could be a sign that in addition to the coalition built is not strong, of the weak consistency of the NGOs' movement in fighting for what they refer to as the "interests of society". This situation is also a big question about how the actual orientation of NGOs in addressing the National Security Bill.

The last important aspect in the coherent unity of interests is the unity in action. As a unity in KMSRK, NGOs coalition also need to have the same action in addressing the problems they encountered in the National Security Bill. The unity of action is as important as the unity of ideas and words. The action taken together is actually an integral part of the unity of ideas and words. From the side of the pressure groups power, the unity of action will be able to provide tremendous pressure on the decision makers. However, if in a coalition, its members are different in ideas and words then generally the action taken will also be different.

In criticizing and addressing the National Security Bill, the NGOs coalition in KMSRK not only have differences in ideas and words. From observations and interviews with informants from NGOs members of the coalition, it is known there are differences in the actions taken by the respective NGOs in addressing the National Security Bill. Some NGOs, such as Imparsial and KontraS, in addressing the National Security Bill in addition to using formal channels, sometimes also conduct a demonstration as an extra-parliamentary movement. As for formal channel, it is through Public Hearing (RDPU) with Commission I of DPR, lobbying to factions in DPR, as well as discussions with the Ministry of Defense and NGOs.

In the case of extra-parliamentary activities, some NGOs like Imparsial, KontraS, YLBHI and LBH Jakarta, have made several rejection action on the National Security Bill. Sometimes Imparsial, KontraS, YLBHI and LBH Jakarta help to mobilize other community groups to reject the National Security
Bill. As the case on February 19, 2013, in which these institutions participated in pushing and fighting together with labors and other elements of society to make a protest on rejecting the National Security Bill. The reason given was, if the bill is passed then it will curb the freedom of civilians to gather. Besides, with the passing of the National Security Bill would muzzle the freedom of expression for civil society, strikes, and demonstration will easily be disbanded by the force for security reasons (Adi, 2013).

As for some other NGOs in KMSRK, such as Lesperssi and IDSPS, according to the informants from both institutions, prefer to use formal channels, such as the Public Hearing (RDPU) with Commission I of the DPR and discussions with the Ministry of Defense.

The difference in the selection of actions among NGOs coalition members can occur because each organization has its orientation and different backgrounds. Some NGOs, such as KontraS and Imparsial, are NGOs known for doing quite often demonstrations because of their background as social movement organizations. When referring to the views of Zanden (1990) and Maran (2001), one of the characteristics of a social movement is active or not passive in managing change. Usually, the social movement takes the form of protests and demonstrations in the scene or in front of the legislature or government buildings.

Related to the difference of action choice amongst NGO coalition members, an informant, namely Bob Sugeng Hadiwinata, argued that the position of KontraS and Impartial cannot be separated from the background of the two. In which the background makes demands of the struggle that is more than just a struggle on the official forums such as lobbying and discussions with the government. As for NGOs such as Lesperssi and IDSPS that choose not to use demonstration, the track is an option that caused by non-confrontational movement model.

Looking at the background of each NGO's organization movement unified in KMSRK, then the different measures or actions taken by each NGO can be tolerated. However, this condition can only be tolerated if the previous sub-indicators of each NGO have the unity of ideas and words. Conversely, if the ideas and words already have differences, the different actions can be interpreted as a rift.

\section{Conclusion}

From the results of the study, it can be concluded that in advocating the National Security Bill, NGOs in KMSRK still perform its role well. There are still shortcomings in running multiple roles, as there are several NGO coalition members that are not running investigative journalism, as a part of strengthening the basis of political education provision. In carrying out the operation as pressure groups, not all NGOs 
carry out or encourage street actions. The difference in this action may actually weaken the strength of the coalition as an opposition group that opposed the government policies.

In the aspect of forming a coherent unity of interests, some disadvantages are also encountered. Among them are still the differences in ideas and words amongst NGO coalition members on whether or not the National Security Law is necessary, there are also differences in action between members of the coalition in addressing the issue of National Security Bill. The emergence of these problems not only make the role of NGOs in advocating the National Security Bill not going well, but it can also be counter-productive in the development efforts for democracy and security sector reform.

From the conclusions above, the recommendation given is the role of NGOs in the security sector reform, one of which is reinforced by forming the unity of ideas and action. NGOs also need to continue to strengthen its role through always be involved in policy-making processes, providing political education, promote or encourage the reform of the security sector, as well as continue to promote public interests.

\section{REFERENCES}

Alaidrus, S. (2015). AJI Gelar Diskusi Ancaman Terhadap Pembela HAM. Antaramaluku.com. Retrieved 10 August 2015, from http://www. antaramaluku.com/berita/28307/aji-gelardiskusi-ancaman-terhadap-pembela-ham

Araf, A. \& Aliabbas, A. (2007). TNI - Polri di Masa Perubahan Politik. Bandung: Program Magister Studi Pertahanan ITB.

Bhakti, I. (2009). Reformasi Sektor Keamanan: Sebuah Pengantar (Panduan Pelatihan Tata Kelola untuk Organisasi Masyarakat Sipil). Jakarta: IDSPS.

Djakfar, Y. (2011). Perwujudan Good Governance di Era Otonomi Daerah. Dinamika - Jurnal Ilmu Sosial Dan Ilmu Politik, 4(8), 26-30.

Ford, M. (2003). NGO as Outside Intellectual: $A$ History of Non-Governmental Organisations' Role in the Indonesian Labour Movement (Dissertation). School of History and Politics, University of Wollongong, Australia.

Gaffar, A. (2006). Politik Indonesia, Transisi Menuju Demokrasi. Yogyakarta: Pustaka Pelajar.

Gavin, C. (2013). The Role of Donors and NGOs in the Security Policy Process in Southern Africa. In A. van Nieuwkerk \& K. Hoffman, Southern African Security Review 2013 (1st ed., p. 38). Johannesburg: The Centre for Defence and Security Management.

Gorman, M. (2002). Global Ageing-The Non Governmental Organization Role in Developing World. International Journal of Epidemiology,
31(4), 782-785.

Hadiwinata, B. (2004). Securitizing Poverty: the Role of NGOs in the Protection of Human Security in Indonesia. Presentation, Singapore.

Harlina, I. (2008). Kedudukan dan Kewenangan KPK (Master Thesis). Master Program, Law Faculty, University of Indonesia.

Heyzer, N. (1998). Government-NGO Relations in Asia: Prospects and Challenges for People-Centred Development. London: MacMillan Press.

Hikam, M. (1999). Demokrasi dan Civil Society. Jakarta: LP3ES.

Huntington, S. (2001). "Mereformasi Hubungan Sipil-Militer". Dalam Larry Diamond dan Marc F. Plattner (ed.). Hubungan Sipil-Militer dan Konsolidasi Demokrasi. Jakarta: PT. Raja Grafindo Pustaka.

Iriye, A. (2004). Global Community: The Role of International Organizations in the Making of the Contemporary World. Berkeley, Calif.: University of California Press.

Joyce, P. (2008). Teach Yourself Politics. London: McGraw-Hill.

Kantaprawira, R. (1987). Pendekatan Sistem Dalam Ilmu-Ilmu Sosial, Aplikasi Dalam Meninjau Kehidupan Politik Indonesia. Bandung: PT. Sinar Baru.

Laksmana, E. (2010). Dari Reformasi Militer Menuju Transformasi Pertahanan: Tantangan dan Prospek Kedepan. Jurnal Indonesian Review: Reformasi Sektor Keamanan Dan Media, 1(1), 1-12.

Latief, A. (1999). Peran Lembaga Swadaya Masyarakat dalam Pengelolaan Sumber Daya Alam Wilayah Pesisir dan Lautan yang Berbasis Masyarakat di Pulau Barrang Caddi Kota Makassar (Master Thesis). Master Degree, Bogor Agricultural Degree.

Liliweri, A. (2005). Prasangka dan Konflik. Yogyakarta: LKIS.

Makaarim, M. (2008). 10 Tahun Reformasi Sektor Keamanan di Indonesia. Presentation, Sulthan Hotel, Jakarta.

Mufrikhah, S. (2011). Peran Lembaga Swadaya Masyarakat (LSM) dalam Pemberantasan Korupsi (Studi Penanganan Korupsi Mantan Bupati Kendal Hendy Boedoro) (Master Thesis). Master Degree Diponegoro University.

Mufti, K. (2015). Civil Society's Role in Security Sector Reform in Lebanon; An Asymmetric Partnership Despite a Growing Working Relations Hip with Security Services. London and Beirut: International Alert.

Mukhibbin, A. (2009). Peran Lembaga Swadaya Masyarakat (LSM) dalam Pengungkapan Kasus Korupsi (Studi Mengenai Peran MCW Dalam Pengungkapan Kasus Korupsi 2,1 M Di DPRD Kota Malang) (Master Thesis). Master Degree 
University Of Muhammadiyah Malang.

Naswar,. (2012). Hak Angket dalam Konstelasi Ketatanegaraan Indonesia. Jurnal Konstitusi, 1(1), 1-13.

PANSUS,. (2016). Pansus RUU Kamnas Panggil Kembali Pemerintah. Dpr.go.id. Retrieved 30 November 2012, from http://dpr.go.id/berita/ detail/id/4524

Praja, A. (2009). Distorsi Peran Lembaga Swadaya Masyarakat dalam Perspektif Civil Society di Kabupaten Grobogan (Master Thesis). Master Degree Program of Diponegoro University.

Prihandoko,. (2012). Mantan Kapolri BHD Bicara RUU Keamanan Nasional. Tempo. co Nasional. Retrieved 5 September 2015, from https://nasional.tempo.co/read/ news /2012/02/21/078385288/mantankapolri-bhd-bicara-ruu-keamanan-nasional

Rahmat, A. (2009). Peran LSM dalam Penguatan Civil Society di Indonesia : Studi Kasus Walhi (Master Thesis). Master Program University of Indonesia.

Sanit, A. (1985). Swadaya Politik Masyarakat. Jakarta: CV Rajawali.

Sasmita, I. \& Pitakasari, A. (2012). Koalisi Masyarakat Sipil Tolak RUU Kamnas, Sebut
Ancam Demokrasi / Republika Online. Republika Online. Retrieved 10 August 2015, from http://nasional.republika.co.id/berita/ nasional/umum/12/10/22/mcaqxh-koalisimasyarakat-sipil-tolak-ruu-kamnas-sebutancam-demokrasi

Susila, S. \& Yulika, N. (2013). Demo DPR, Buruh Tolak RUU Ormas dan Kamnas. Metro.news.viva.co.id. Retrieved 12 August 2015, from http://metro. news.viva.co.id/news/read/391485/demodpr--buruh-tolak-ruu-ormas-dan-kamnas

Theuri, N. (2014). Indicators of NGOs Success \& Impacts on NGOs Role in HIV Policy Process in Kenya. Malmo University.

Tolak RUU Kamnas, Bakar Ban di Gerbang DPR. (2012). detiknews. Retrieved 29 December 2014, from http://news.detik.com/fotonews/2077809/tolak-ruu-kamnas-bakar-bandi-gerbang-dpr $/ 1$

Willetts, P. (2012). What is a Non-Governmental Organization? UNESCO Encyclopaedia of Life Support Systems. London: City University Press.

Winanto, S. (2008). Efektifitas Strategi Organisasi Masyarakat Sipil dalam Advokasi Reformasi Sektor Keamanan di Indonesia 1998-2006. Jakarta: IDSPS. 